Communications in Information Literacy

Volume 10 | Issue 1

Article 6

6-6-2016

\title{
Empowering Students to Make Sense of an Information Saturated World: The Evolution of Information Searching and Analysis
}

James $\mathrm{H}$. Wittebols

University of Windsor, jhw@uwindsor.ca

Follow this and additional works at: https://pdxscholar.library.pdx.edu/comminfolit

Let us know how access to this document benefits you.

\section{Recommended Citation}

Wittebols, J. H. (2016). Empowering Students to Make Sense of an Information Saturated World: The Evolution of Information Searching and Analysis. Communications in Information Literacy, 10 (1), 1-13. https://doi.org/10.15760/comminfolit.2016.10.1.18

This open access Perspective is distributed under the terms of the Creative Commons Attribution-NonCommercialShareAlike 4.0 International License (CC BY-NC-SA 4.0). All documents in PDXScholar should meet accessibility standards. If we can make this document more accessible to you, contact our team. 


\section{EMPOWERING STUdEnTS TO MAKE SENSE OF AN INFORMATION-SATURATED WORLD}

\section{The evolution of Information Searching and Analysis}

James H. Wittebols

University of Windsor
How well students conduct research online is an increasing concern for educators at all levels, especially higher education. This paper describes the evolution of a course that examines confirmation bias, information searching, and the political economy of information as keys to becoming more information and media literate. After a key assignment in which students assess their own tendency to engage in confirmation bias, students research a social justice issue across web, news and academic research resources. Designed to build good analytical skills in assessing the trustworthiness of a variety of sources of information, the course empowers students as researchers, citizens and consumers.

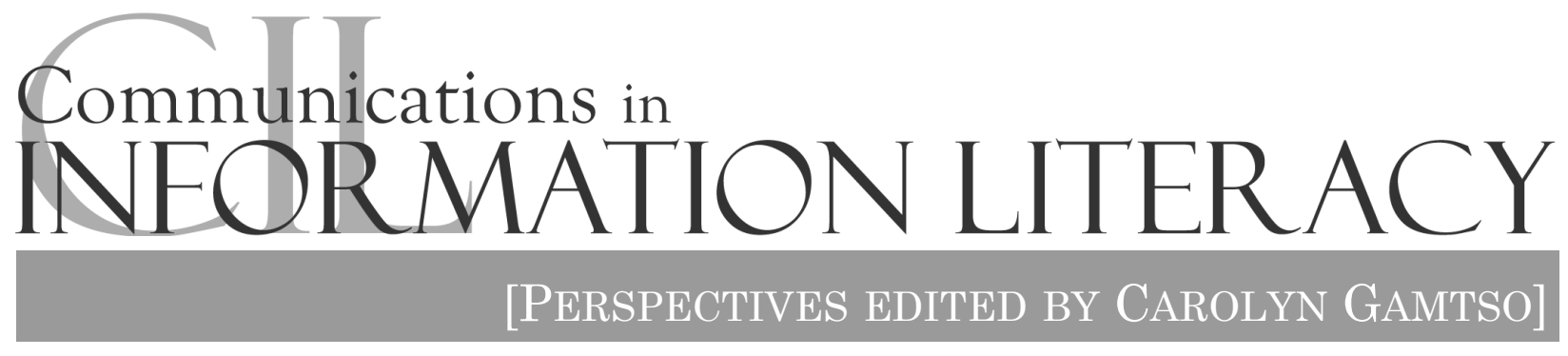




\section{INTRODUCTION}

Information literacy has become a buzz phrase of the new century. Thirty years of digital technology development have made searching for information decidedly easy. The results of the searching, however, often leave much to be desired. This paper will detail how a course focused on information literacy was devised and implemented.

Several years ago, I began to see problems with how students used information gathered online. I came up with a unit in my Sociology of the News Media course that focused on how to judge the integrity of a news website. While that assignment seemed helpful, I sensed that there were some larger issues involved that meant I needed to work further into how students do research electronically in order to get them to do their research more critically.

The larger issues involved human curiosity, a misplaced faith in search engines, and our propensity to engage in confirmation bias. "Confirmation bias" is the term used for our tendency to be psychologically invested in the familiar and in what we already believe, and to be less receptive to information that contradicts what we believe (Nickerson, 1998). The multi-layered problems related to the idea of information literacy ultimately led to the realization that a full course was necessary. Information literacy is not just a matter of mechanics, but also involves understanding the importance of cognitive dissonance and the problem of confirmation bias as integral elements in helping students become better able to sort out information that is reliable and trustworthy.

The theoretical elements behind this new course draw upon the educational philosophy of Paulo Friere, whose work focused on helping illiterate Brazilians become critical citizens and agents (Friere, 1970; Shor, 1980). His method helps students work through the social contradictions that foster social injustice and inequality. Friere gets students to question the given state of affairs about their lives and helps them look at their situation in a new way. It is a "fish out of water" discovery process wherein a fish that has only experienced water as a living environment discovers there are other ways to live in the world. The "fish out of water" is experiencing cognitive dissonance (Festinger, 1964), a situation in which a person's worldview is disrupted by new information which contradicts or supplants the current view. An individual experiencing this dissonance can deal with it in one of two ways: reject the new source of information and reinforce the existing worldview, or weigh the truth value of the competing viewpoints and determine if the closely-held views should be revised. The former we have identified as confirmation bias, which does not challenge the reader to resolve the contradiction. The latter approach is more demanding on learners, but opens the possibility of changing one's views.

Friere is very salient with regard to a more critical approach to cognitive dissonance. Rather than teachers depositing their knowledge in students (which he calls banking education), he sees education more as a dialog between students and teachers, where teachers play a facilitating role in helping students discover and analyze the social world. Friere is mindful of the process by which people change their 
worldview when discovering a new source of information. Employing confirmation bias to "resolve" the contradiction is the easy, if lazy, approach individuals tend to engage in without being fully aware of doing so. The challenge to educators is to disrupt that process by having students confront their tendency

\begin{tabular}{|c|c|}
\hline $\begin{array}{l}\text { bias } \\
\text { thout an authority } \\
\text { ure preaching at } \\
\text { m. This practice } \\
\text { ows them to confront } \\
\text { ir own worldview } \\
\text { d moves them to } \\
\text { tically engage new } \\
\text { ormation in a way } \\
\text { t might result in a } \\
\text { ange of } \\
\text { ssciousness. By } \\
\text { fronting their }\end{array}$ & $\begin{array}{l}\text { THE INSTANTANEOUS } \\
\text { NATURE OF DIGITIZED } \\
\text { INFORMATION PRESENTS } \\
\text { AN ILLUSION OF UBIQUITY } \\
\text { AND RELIABILITY AND } \\
\text { GIVES STUDENTS A SENSE } \\
\text { OF KNOWING ABOUT THE } \\
\text { WORLD THAT CAN BORDER } \\
\text { ON DELUSION. }\end{array}$ \\
\hline
\end{tabular}

people's adaptation of the Internet in their lives. The researchers presented two opposing scenarios for how young people will use the Internet in the future. Briefly, the first scenario was the optimistic oneyoung people would not suffer notable cognitive shortcomings. They would be able to think deeply, successfully multitask, search effectively, and access collective intelligence. The second scenario was more pessimisticyoung people would have difficulty retaining information; spend energy on short messages and entertainment; lack face -to-face skills; and depend on technology in unhealthy ways. their closely-held beliefs individually, students are much freer to change their minds and to deal with new information in a less dismissive manner. The relationship between confirmation bias and cognitive dissonance applies in two ways in the course Information Searching and Analysis. First, students are more aware of their own tendencies as they search and think about their self-chosen issue. Second, students are made aware of the personalization incorporated in search algorithms as a form of confirmation bias.

\section{TODAY'S STUDENT AND THE INTERNET}

In 2012, the Pew Research Center's Internet and American Life project (Anderson \& Rainie, 2012) released a report on young
The researchers posed these scenarios to a carefully selected set of experts on youth and technology. While 55\% agreed with the optimistic scenario, $42 \%$ were more pessimistic. Of the optimists, many recognized that their view was more of an aspiration, and many questioned said that the reality would be a combination of the two scenarios.

However, one participant (Wesley George, principal engineer at Time Warner Cable) concluded:

The difference between the two scenarios will come down to the ability of our educational system to teach people how to manage the flow of information, the interaction 
between personal and work, social and entertainment, fact and opinion... the focus must be on the fact that learning means knowing how to filter and interpret the vast quantities of data one is exposed to-we must use the fact that the Internet has all of this information to spend less time doing rote memorization and more time on critical thinking and analysis of the information that is available to you. (Anderson \& Rainie, 2012, p. 22)

Anyone who works with young people will acknowledge that today's youth place a value on speed and immediacy. Small and Vorgon (2008) argue that time on the Internet brings changes in the way the brain functions, prioritizing fast processing over reflective decision making. Students use the Internet in a utilitarian fashion, employing digital technologies to accomplish a task quickly; they tend to prioritize means over ends and "getting it done" over "getting it right." This tendency results in students taking short cuts that may undercut learning and knowledge (Swanson, 2011). In this case, the Internet and digital searching become crutches for students, and the haste to "get it done" creates work that is less than sufficient.

The instantaneous nature of digitized information presents an illusion of ubiquity and reliability and gives students a sense of knowing about the world that can border on delusion. Speed and popularity seem to be the primary values guiding the use of technology, but such values may also run contrary to what makes information truly valuable - that it is reliable and valid over time.
Many people assume that today's students are technologically savvy; however, this often proves fallacious (Albitz, 2007). A good example of this misconception is the 2014 revelation that Facebook was using its service to conduct research on unwitting users; the research tested whether manipulation of Facebook's news feed could alter users' moods (Dewey, 2014). When I asked students in my classes in the subsequent semesters whether they had heard of this development, those who had were a small minority. Similarly, students have limited knowledge about the function of algorithms and how that function shapes their experiences on the Internet. Algorithms are mathematical formulae that execute a set of instructions to achieve a desired outcome. In online searches, algorithms are used to deliver "relevant" content and advertising to a user based on the user's previous web "history." Algorithms are used to deliver search outcomes, news, and advertising based on the user's profile as constructed by their web behavior-purchases, comments, previous web searches and other digital "droppings" users supply as they navigate the Internet.

Familiarity with navigating social media, websites and applications tells students nothing about the value of what they are reading. Studies of students' assessment of websites generally conclude that they engage in cursory analysis and heuristic methods to assess the value of a website. Some of those heuristic methods reflect a short cut and a utilitarian orientation, equating popular with good (Metzger, Flanagan \& Madders, 2010) and valuing currency (Case, 2003), reputation, and selfconfirmation (Metzger \& Flanagan, 2013) 
as ways to assess websites. In particular, Metzger and Flanagan cite "expectancy violation" or the tendency to dismiss unexpected information as not credible. We will see that this tendency parallels problems of confirmation bias.

\section{PHILOSOPHICAL UNDERPINNINGS AND RELEVANT LITERATURE}

Underlying my desire to help students independently evaluate the results of Internet searches was my recognition that the philosophy of Paulo Friere would be key in developing this course. His "problematizing" method of education fits perfectly into the course's philosophy, a sentiment found with some frequency in the literature on critical information literacy (Jacobs \& Berg, 2011; Elmborg, 2006; Swanson, 2004). As noted earlier, Friere uses the "fish out of water" analogy to get students to question what they know about the world. By "extraordinarily reexperiencing the ordinary," (Friere, 1970) and questioning the "taken-for-grantedness" of the Internet, students in Information Searching and Analysis could become more critical users of the Internet and apply the skills learned to their daily lives, not only as students, but also as citizens and consumers.

A second element of the course derived from the work of Friere is having students choose the issue they will focus on for the semester. I teach at a university where the social science faculty has historically taken social justice as a pinnacle. As a long-time activist and social scientist, I have a broad range of knowledge on social justice issues and know where to direct students when my knowledge runs thin. In the first two weeks of the course, students commit to researching a social justice issue for the rest of the semester. When students conceive a topic too broadly ("Why US elections don't produce democracy"), I help them funnel the topic down to something more manageable (voter ID laws or gerrymandering or campaign finance reform). When they have defined something too narrowly, I help them make the topic more globally applicable. I also ask students to consider how strongly they feel about the issue, as they will undoubtedly have to consider perspectives to the contrary.

The third way in which Friere has influenced the development of the course is my avoidance of the term "information literacy" in the title and in course materials. The term "literacy" implies deficit, and I regard this phrase as a poor way to frame the issue for students (Jacobs \& Berg, 2011). My idea is to help students become aware of and begin to master the traps of today's digital information environment.

This idea extends to Friere's thoughts about "teachers" and "learners" as false dichotomies. As Hall (2010) argues, teaching in today's world should be about helping students remain curious and think independently and critically. Following Swanson (2004), who encourages faculty to give up some of that traditional "authority" historically assigned to professors, I perceive my role in this course to be one of a facilitator of learning. I see this course as an example of the "flipped" classroom (Arnold-Garza, 2014), involving group learning and discussion with only an occasional orientation lecture. Assignments are judged largely on the basis of thoroughness and attention to detail. The 
goal is to see students build good habits as researchers, and the assignments detailed below are meant to be assessments of meticulous learning by students.

These themes related to Friere's philosophy appear in much of the literature in the area of critical information literacy: Weaver and Tuten (2014) encourage methods which help individuals question their own thinking and perceive ingrained thought processes. Valentine and Wukovitz (2013) point out the value of making people confront alternative views by maintaining that cognitive dissonance disrupts our worldview, thus acting as a catalyst for learning.

\section{WEBSITE ANALYSIS ASSIGNMENT}

In 2007, I began to incorporate into courses an assignment designed to problematize information searching on the web, beginning with a website analysis project in a course called Sociology of the News Media. Students were charged with accessing news sites and judging the quality and viability of the news at those sites. I directed the students to the University of California at Berkeley Library website's research tools: a page titled "Evaluating Web Pages: Techniques to Apply and Questions to Ask" at http:// www.lib.berkeley.edu/TeachingLib/Guides/ Internet/Evaluate.html served as a guide for completing the assignment. The assignment was to evaluate news sites they considered to be credible, and to review a variety of assigned news sites and determine the trustworthiness of each site.

Based on the quality of work of most students, the assignment worked in terms of helping them realize that not all websites are equal and that a professional "look" to a website could be a form of deception. To the degree that students follow national and global events, they are increasingly using their phones to do so, and they expect access to news for free. As part of this assignment, students came to realize that most news still comes from newspapers (now perhaps better termed news organizations), or from wire services that sell to newspapers. I also pointed out that advertising of any kind tends to shape the kind of news presented. The assignment forced them to look at more independent efforts in news at not-for-profit news media, and at media sources driven largely by subscriptions. In discussion, I posed to them how such efforts may be meaningful, but could they be viable in an Internet environment that seems to value "free" over all else?

Thus, I brought a political economy analysis to my students' understanding of information literacy. A political economy analysis concerns itself with the social struggle over the production, distribution and consumption of resources (Mosco, 1996). Seeing information increasingly as a commodity-something to be bought and sold on the market - requires students to be aware of the corporate digital powers increasingly governing the information environment.

While raising these issues had value in itself, and the assignment hopefully helped students to build "good habits" of research on the net, it was increasingly clear to me that there was much more to problematize, discuss, and research about how we access information as students, researchers, 
consumers and citizens. I recognized the questions posed by political economy analysis of the news media; questions such as "Who pays for it? What are their motives? How do news media relate to other centers of power (ex. economic and political)?" are all important considerations for the larger information environment as well. A full course on this topic was both needed and invaluable if it could tap into student's needs and experiences, and if it could demonstrate the significance of being a critical consumer of information wherever it is found.

What was to become Information Searching and Analysis began as a special topics course in a Political Science Department. The first three attempts at this course were hampered by low enrollment that made assessment of its effectiveness more difficult. As an elective, the course attracted students across many disciplines, from the social sciences to business. There were, however, many individual successes among students in these first attempts that made continuing to evaluate and modify the course a worthwhile activity. The course was built around searching on the Internet. It included the website analysis assignment developed in the news media course, but placed it well into the middle of the semester after the class had examined myriad psychological and political economy implications of how we receive and process information.

\section{TEXTS AND READINGS}

Since developing the course, I have consistently used one book. UnSpun: Finding Facts in a World of Disinformation by Brooks Jackson and Kathleen Hall
Jamieson is a user-friendly dissection of news media, promotional practices, and the new forms of propaganda. A chapter on confirmation bias serves as the starting point for that particular assignment. Eli Pariser's The Filter Bubble: How the New Personalized Web is Changing What We Read and How We Think was an early book to explain and critique search personalization. Chapters on the psychology and political economy of information are valuable in helping students become more critical information consumers. The readings from these books provide evidence to students that they need to have a "headsup" approach and encourage more discretion and critical thinking in web searching.

\section{COURSE Elements/}

\section{ASSIGNMENTS}

This is a "blended" course that meets a great deal for the first six weeks; it meets less often as students complete their major assignments. In the first few weeks, I convey basic Internet understanding, such as the meaning of suffixes and the importance of multiple search terms and phrases. Early versions of the course included an assignment on analyzing search results across search engines using the same search term or phrase; this assignment is now built into a course session as a demonstration that students perform in groups.

The key accomplishment for students early in the course is a critical assessment of how our own psychological tendencies can bias our evaluation of information. This assignment helps students develop some tools to realize when they are engaging in confirmation bias. The assignment, which 
focuses on our tendencies to find and value information that agrees with our preferred position, proved to pay off many times over. Students were tasked with taking a weekend to look for confirmation bias in popular culture, in their friends and family, and most importantly, in themselves. Using a chapter from unSpun which outlines six ways in which both individuals and the media encourage us to engage in confirmation bias, students find the task of discovering examples of each in their lives to be challenging, but also rewarding and selfrevealing.

Another class session focuses on search personalization. Students conduct searches based on their popular culture preferences or interests. For example, a student who follows football may conduct footballrelated searches (for news, for team logo clothing, for tickets), while another student searches for youth football leagues and equipment. They then both search on the term "concussions." The results each of them gets vary substantially. This exercise helps students realize that the Internet is watching their digital behavior and predicting what they want to hear-another form of confirmation bias that students almost universally "get." The exercise accompanies several assigned chapters from The Filter Bubble that detail the psychology and political economy of search personalization.

In terms of independent effort, the three major assignments are the website evaluation, the news analysis, and an annotated bibliography. The website analysis is the assignment developed initially for the news media class that is now better contextualized in the new course. Additionally, a formal evaluation form, with

\section{Table $1-$ Course Assignments, OBjectives and Value to Course}

\begin{tabular}{|l|l|l|}
\hline Assignment & Objective/Purpose & Value to Course Goals \\
\hline A. Confirmation Bias & $\begin{array}{l}\text { To endow students with an } \\
\text { awareness of our tendencies }\end{array}$ & $\begin{array}{l}\text { Students begin to "check" } \\
\text { themselves by reading sources } \\
\text { differently }\end{array}$ \\
\hline B. Website Analysis & $\begin{array}{l}\text { To define the issues related to } \\
\text { social justice topic } \\
\text { To understand the "players" and } \\
\text { their views on the issue }\end{array}$ & $\begin{array}{l}\text { Learn to discriminate among } \\
\text { Internet resources } \\
\text { Linked to A, can now better } \\
\text { critically assess truth claims on } \\
\text { the Internet }\end{array}$ \\
\hline C. News Analysis & $\begin{array}{l}\text { To promote news literacy } \\
\text { To help students determine how } \\
\text { news media frame their issue }\end{array}$ & $\begin{array}{l}\text { Read news differently; see that } \\
\text { not all news is the same } \\
\text { Differentiate between news and } \\
\text { opinion }\end{array}$ \\
\hline D. Annotated Bibliography & $\begin{array}{l}\text { To determine the themes and } \\
\text { findings that emerge from } \\
\text { trustworthy websites, news } \\
\text { sources and academic literature }\end{array}$ & $\begin{array}{l}\text { To see how research deemed } \\
\text { trustworthy lines up with news } \\
\text { reports and popular websites }\end{array}$ \\
\hline
\end{tabular}


extensive instructions and guidance so students can work confidently and independently, was developed for both this assignment and the news analysis assignment.

The news analysis assignment has also evolved from an emphasis on use of "prestige" or "serious" newspapers. With a lecture on the nature of the news industry, students now search a variety of news organizations on their topic to get a good flavor of how politicized news media can be. The assignment serves as a news literacy experience, where students identify the selection of human and data sources cited in the news report as keys to uncovering the underlying perspective that exists in many stories in the media. This approach helps students determine if a particular perspective is favored in a news story and encourages them to assess the range of perspectives available across the range of news stories under analysis. The objective of the assignment is to have students understand what themes and frames are popular in news portrayals of their issue.

The annotated bibliography is the capstone assignment for the course. Students annotate the websites they deemed trustworthy; the news articles they assessed as credible; and related, peer-reviewed academic literature on the topic. Table 1 summarizes the four major learning experiences that comprise the heart of the course.

\section{LEVELS OF ANALYSIS FOR STUDENTS}

Ultimately, students emerge from the course more empowered to judge, analyze and critique information available at three basic levels:

- The "Wild West" of the Internetunderstanding today's search engines and social networking sites and the myriad claims to truth that pervade interest group websites helps them become more skeptical users of the Internet and develop a trustworthy set of sources to consult regularly.

- The popular understanding of a social justice issue via analysis of news media perspectives, and whose themes ultimately frame social discourse on the issue.

- How peer-reviewed research is reflected (or not) in news reports, as well as in various news and interest group websites. Students get a sense of whether the considerable resources invested in research influences the development of social discourse and policy.

In meeting these goals, the course accomplishes substantially more than the "how-to" teaching component where the teacher "reveals" truths. By the time students have worked through the assignments, they have become not only smarter about how to access information, but critical thinkers about information. The semester-long look at a social justice issue now has a context that incorporates the socio-political world's understanding and discourse about that issue. Students can now begin to discern the limits on social discourse around an issue by analyzing the 
breadth of perspectives on that issue in popular media, especially in the digital information environment.

The net effect the news media may have on social debate in the ways issues and solutions to issues are framed and often bounded is informed by political economy analysis of the information environment. In advancing their knowledge about the political economy of information, students hopefully will take the attitude that their trust of media outlets needs to be earned by those outlets. While I originally wanted to get students to be better researchers, the course's breadth has meant I could accomplish much more, especially with students willing to explore their own confirmation bias tendencies. Students are much better to able to assess the quality of political debate among elected representatives, evaluate the quality of news as it appears across the many different retrieval options, and analyze how well the public is informed about peer reviewed research on a social justice topic. In terms of Frierean education philosophy, students have re-experienced the Internet not as a fast, efficient way to research; they have come to understand its traps, particularly its tendency to employ searching as a form of confirmation bias.

\section{STUDENT REACTION}

Student reflection on the course through end-of-semester reflection papers provides insight into how a Frierean approach to information literacy works with students. The assignments offer an experience of empowerment, and students come to feel greater control over the search process. Having learned some important aspects about themselves, specifically their tendency to engage in confirmation bias, most students cited that assignment as their favorite; they reported being better table to catch themselves engaging in confirmation bias. A majority said they look at websites and news differently and that the course had value beyond the classroom. The three quotes below add some detail to these results:

I am now far more literate in critiquing what I am being told due to reading filter bubble and unSpun...This has translated positively into my other courses by allowing me to research more effectively...this has also transferred to my personal life as well, I often catch myself wondering where they heard it, what the evidence is, and whether it was a credible source or not.

The confirmation bias assignment was one of the more difficult assignments. I think the reason lies with its introspective nature identifying areas where you may become more predisposed to react to something on an emotional basis instead of objectively is an incredibly hard but rewarding process.

This assignment was very interesting because it required you to seek an answer that does not please you, taking you out of your comfort zone making you look at a subject from all different aspects and angles.

It should be noted that these articulate and condensed remarks are reflective of about 
two-thirds of the reflection papers submitted. In future offerings, I will conduct a more rigorous evaluation which tests growth in critical thinking, specific changes in how students do research, and students' ability to translate and assess news media reports. The goal of the assessment will be to determine just how effective and how pervasive such effects are among all students in the course. While not the only approach to achieving these outcomes (in terms of exclusivity), the evolution of Information Searching and Analysis provides a road map for other scholars seeking to enhance and empower student learning.

The course can be adapted to any discipline. For example, some approaches could involve the whole class on the issues surrounding food by having groups of students focus on an element of the issue (marketization and distribution, nutrition, food as culture, the role of climate change, etc.). The news assignment is malleable to many topics and conveys benefits to students as consumers and citizens. The use of an annotated bibliography allows students to reach some conclusions about a topic that is important to them or has become important to them as a result of their work. Thus students become more empowered and confident about making sense of the world.

\section{CONCLUSION}

The learning outcomes from Table 1 demonstrate that the course's impact goes beyond how well students do research. The course can have positive impacts in their daily lives as citizens and consumers. By building "good habits" of assessing websites and news media, students become critical consumers of information in an informationsaturated world. The need for a course such as this will only increase as we become more dependent on digital technologies to negotiate the world we live in. There is much to be argued for implementing critical information literacy programs in schools, and for continuing education programs in communities. As almost everyone engages the online world, public libraries could become a center for this kind of activity. At the university level, it would not be hard to implement such a course in many departments concerned with the quality of their students' research and with how well their disciplinary concerns translate into the popular imagination through today's information environment. There are examples of creative approaches in crossdisciplinary efforts at critical information literacy as well. Courses developed around themes such as food (Piper \& Tag, 2011) or genetics (Swanson, 2004) allow students to get an interdisciplinary perspective on a broad-ranged and socially important issue. This interdisciplinarity extends student learning beyond their individual project to an appreciation of the work of other students and groups in the course.

Faculty can also count on campus librarians in this area, as critical information literacy is a popular subject among those who deal directly with the changes digital information environments have wrought (Albitz, 2007; Elmborg, 2006; Swanson, 2004). Often frustrated by working with a small confined unit within college courses, librarians are eager to take on many of the tasks associated with a course like this one. From the students' perspective, they are less intimidated by library work if they 
encounter someone who is knowledgeable about the course and who understands the underlying principles the course is trying impart.

\section{REFERENCES}

Albitz, R. S. (2007). The what and who of information literacy and critical thinking in higher education. portal: Libraries and the Academy, 7(1), 97-109. $\quad \underline{\mathrm{http}: / /}$ dx.doi.org/10.1353/pla.2007.0000

Anderson, J. Q. \& Rainie, L. (2012). Millennials will benefit and suffer due to their hyperconnected lives. Pew Research Center Internet and American Life Project. Washington, DC.

Arnold-Garza, S. (2014). The flipped classroom teaching model and its use for information literacy instruction. Communications in Information Literacy, 8 (1), 7-22.

Case, Roland (2003). Making critical thinking an integral part of electronic research. School Libraries in Canada, 22(4), 13-16.

Dewey, C. (2014, July 1). Nine answers about Facebook's creepy emotional manipulation experiment. Washington Post. Retrieved July 5, 2014 at http:// www.washingtonpost.com.

Elmborg, J. (2006). Critical information literacy: Implications for instructional practice. The Journal of Academic Librarianship, 32(2), 192-199. http:// dx.doi.org/10.1016/j.acalib.2005.12.004

Festinger, L. (1964). A Theory of Cognitive
Dissonance. Palo Alto: Stanford University Press.

Friere, P. (1970). Pedagogy of the Oppressed. New York: Herder \& Herder. Hall, R. (2010). Public praxis: A vision for critical information literacy in public libraries. Public Library Quarterly, 29(2), 162-79. http://dx.doi.org/10.1080/ $\underline{01616841003776383}$

Harris, B. R. (2012). Subversive infusions: Strategies for the integration of information literacy across the curriculum. The Journal of Academic Librarianship, 39(2), 175-180. http://dx.doi.org/10.1016/

j.acalib.2012.10.003

Jacobs, H. and Berg, S. (2011). Reconnecting information literacy with the core values of librarianship. Library Trends, 60(2), 383-394. http://dx.doi.org/10.1353/ $\underline{\text { lib.2011.0043 }}$

Metzger, M. J. \& Flanagin, A. J. (2013). Credibility and trust of information in online environments: the use of cognitive heuristics. Journal of Pragmatics, Part B, 59, 210-220. $\quad$ http://dx.doi.org/10.1016/ j.pragma.2013.07.012

Metzger, M. J., Flanagin, A. J. \& Medders, R. B. (2010). Social and heuristic approaches to credibility online. Journal of Communication, 60(3), 413-439. http:// dx.doi.org/10.1111/j.1460-

2466.2010.01488.x

Mosco, V. (1996). The Political Economy of Communication. London: Sage Publishers.

Nickerson, R. (1998). Confirmation Bias: A 
ubiquitous phenomenon in many guises. Reviews of General Psychology, 2(2), 175$220 . \quad$ http://dx.doi.org/10.1037/10892680.2.2.175

Piper, P. \& Tag, S. (2011). Theme-based information literacy instruction. College and Undergraduate Libraries, 18(4), 319-332. http://dx.doi.org/10.1080/ $\underline{10691316.2011 .624956}$

Shor, I. (1980). Critical Teaching and Everyday Life. Montreal: Black Rose Books Small, G. and Vordan, G. (2008). Meet your brain. Scientific American Mind, 19(5), 4249.

Swanson, T. (2011). A critical information literacy model: library leadership within the curriculum. Community College Journal of Research and Practice, 35(11), 877-894. http://dx.doi.org/10.1080/ $\underline{10668920802290057}$

Swanson, T. A. (2004). A radical step: Implementing a critical information literacy model. portal: Libraries and the Academy, 4 (2), 259-273. http://dx.doi.org/10.1353/ pla.2004.0038

Valentine, A. \& Wukovitz, L. (2013). Using The Filter Bubble to create a teachable moment. Pennsylvania Libraries: Research and Practice, 1(1), 24-34. http:// dx.doi.org/10.5195/palrap.2013.18

Weaver, K. D. \& Tuten, J. H. (2014). The critical inquiry imperative: Information literacy and critical inquiry as complementary concepts in higher education. College and Undergraduate Libraries, 21(2), 136-144. http:// dx.doi.org/10.1080/10691316.2014.906779 